\title{
Civilization's Effect on Wildlife
}

\author{
By H. M. Rayner, Ituna.
}

$\mathbf{I}^{\mathrm{N}}$ MY LAST LETTER to The Blue Jay I referred to the changes that have been gradually and continuously going on in the physical aspect of the countryside that I write of, and of their effect on wild life. Though the vagaries of climate and weather have played a part, settlement of the country and the activity of man have been a disturbing factor, too. In this and subsequent letters I want to talk about some of the e:fects on wild life of settlement and cultivation.

When my father homesteaded near the present site of the village of Ituna in 1904, the country was inhabited only by a few widely scattered ranchers and Metis squatters. I remember a neighbouring homesteader telling my father, how he had shot one of his own tame white ducks by mistake.

"What did you think it was?" my father asked.

The reply meant nothing to me at the time. Now it will be full of significance for all Blue Jay readers: "I thought it was some kind of white crane; we'd seen some such birds around."

I never saw a whooping crane alive, and those seen by our neighbour must have been the last of their race in these parts.

In the years 1904 and 1905, the varying hare (which I will after refer to by its familiar name of rabbit) reached a peak of abundance that has not since been equalled here. The bluffs literally teemed with them; you could not take ten steps without starting a rabbit.

Destruction was impending. Already it was a common experience to find a rabbit affected with watery cysts, and unfit for food. The work of the parasitic worms was fast and deadly. Within two years it was hard to find a track of even one lone survivor.

The cyclic periods of abundance and scarcity are well known, and I am concerned here only to show how economic factors and the hand of man came into the picture. I think it was about 1924 that a market arose for rabbit pelts for the felt industry. As times for farmers were none too good (or we thought they weren't) there was a great slaughter of rabbits just as they were beginning to recover from a low point in the population cycle.

From this blow they might have recovered (for they are resilient little creatures) had not the fox farmer followed closely in the wake of the felt manufacturer.

The poor little Snowshoe Rabbit is quite a rarity now. So too is his large and handsome cousin, the Jack. But perhaps his luck has turned at last. Fox fur has slumped, and most farmers have pelted their foxes and quit the business. It is no longer a profitable sideline. Will the rabbits come back?

Why one should want them back may be a puzzle to some people. Aren't they only pests, that girdle trees and make havoc in gardens?

This brings us to a really important and fundamental quesiion. It is cur attitude towards wild life. Mysel:, I hold the view that all our native wild animals (I include birds) merit conservation; that all ought to be guarded against such reduction of numbers as might threaten the survival of the species. Even rabbits -our rabbits-are of some "use". They provide natural food for other species which in time of dearth are driven to raid the farmyard. That is the economic side. But isn't the aesthetic side of even more importance?

Some of my own most cherished memories are of the little "Snowshoes" coming out of the woods into the open at sunset, and, silhouetted against the darkening bluff, jumping almost vertically upward (like ghostly jack-in-the-boxes) to reach and nibble the tender shoots of young poplars. Another memory is of the days when the "Jacks" would come to the haystack in the light of a full moon; not in twos and threes but by dozens; loping along, one behind another, Indian file, in mute procession.

Such sights made life a rich experience. Memories of them are lasting wealth. How lonely now is 
the winter prairie, without these wild earth-born companions for company! How much those who come after us will miss, by not having them to arouse interest, stimulate curiosity, and challenge insight!

\section{PREDATORS}

By Stuart P. Jordan

I HAVE OFTEN SEEN robin's eggs lying on roads, sidewalks and open fields and this spring was no exception. I was naturally puzzled as to how they got there and what bird dropped them. I was therefore rather surprised to see a male robin boldly alight on a curb with a freshly punctured egg in his bill. This observation might partially explain the how and what, but the why for me still remained unanswered.

Do male rivals attack the nests of victorious suitors?

\section{Curiosity or Emotion?}

By Cliff Shaw

$\mathbf{H}$ EMMED IN on either side by huge banks of snow twelve deer raced for their lives ahead of a speeding locomotive, near York Lake, March 27, ending in the death of three does.

Game guardian Harold Deighton explained that the engineer, in accordance with the law, stopped his train and bled the animals, then reported their death on arriving in Yorkton. When Mr. Deighton went out an hour later to recover the carcasses, he found that seven deer had returned to the tracks, "apparently seeking their dead companions."

We wonder what prompted those seven deer to again risk their lives. Was it curiosity or emotion?

\section{GRASS}

By John J. Ingalls

Lying in the sunshine among the buttercups and dandelions of May, scarcely higher in intelligence than the minute tenants of that mimic wilderness, our earliest recollections are of grass; and when the fitful fever is ended and the foolish wrangle of the market and forum is closed, grass heals over the scar which our descent into the bosom of the earth has made, and the carpet of the infant becomes the blanket of the dead.

"Grass is the forgiveness of Nature - her constant benediction. Fields trampled with battle, saturated with blood, torn with the ruts of cannon, grow green again with grass; and carnage is forgotten. Streets abandoned by traffic became grassgrown like rural lane and are obliterated.

Sown by the winds, by wandering birds, propagated by the subtle agriculture of the elements which are its ministers and servants, it softens the outline of the world. It bears no blazonry of bloom to charm the sense with fragrance or splendor, but its homely hue is more enchanting than the lily or the rose. It yields no fruit in earth or air, and yet should its harvest fail for a single year, famine would depopulate the world.

In spite of protective laws and the fact that the broad-winged hawks are beneficial to man as rodent destroyers, any number of hunters and farm boys take pot shots at these slow wheeling birds. The situation is so serious according to the $\mathrm{Na}$ tional Audibon Society, that "the senseless slaying of hawrs has brought some of them within risk of extermination."

\section{SQUATTER'S RIGHTS}

ST. ALBANS, England, June 6 (Reuters). - Carl Jameson didn't realize what was going on behind his back. He just peddled his bicycle to and from work every day.

All the time a stubborn robin was building a nest in the saddle bag of Jameson's bike.

Tuesday he had to leave the bike until a young robin could fly away and leave the vehicle to him again.

"Would like to compliment you on this splendid production. It is much more attractive and convenient in the new form. The material also is of great interest." -E. L. Paynter, Game Commissioner. 